\title{
PEMANFAATAN WHATSAPP GRUP SEBAGAI MEDIA KOMUNIKASI DI DAERAH PEDESAAN
}

\author{
Ririn Puspita Tutiasri ${ }^{1}$, Wahyu Santoso ${ }^{2}$, Aulia Rahmawati ${ }^{3}$ \\ ${ }^{1-3}$ Universitas Pembangunan Nasional Veteran Jawa Timur \\ 1ririn_puspita.ilkom@upnjatim.ac.id, ${ }^{2}$ wahyu.agri@upnjatim.ac.id, \\ ${ }^{3}$ aulia_rahmawati.ilkom@upnjatim.ac.id
}

\begin{tabular}{l}
\hline \hline Article Info \\
\hline Article history: \\
Received 3 Januari 2021 \\
Accepted 10 Februari 2021 \\
Published 1 April 2021 \\
\hline
\end{tabular}

Keyword:

Media Komunikasi, Grup

Whatsapp, Daerah

Pedesaan.

\section{Abstract}

Technological developments are able to change the habits or culture of an area, including the way people communicate. One of the technologies that change the way of socializing is through the Whatsapp application. The focus of this research is how to use Whatsapp groups as a communication medium by the community in Pandowan Village, Galur District, Kulon Progo Yogyakarta. The purpose of this study was to describe the use of Whatsapp groups as a communication medium by the community in Pandowan Village, Galur District, Kulon Progo Yogyakarta. This research method uses descriptive qualitative research. The results of this study indicate that the use of Whatsapp groups as a means of exchanging information on village government with the community and fellow villagers. Utilization through whatsapp groups is used as a means of delivering village government policies, conversations, and discussions between residents about village government policies.

Perkembangan teknologi mampu merubah kebiasan atau budaya suatu daerah, termasuk tata cara berkomunikasi masyarakat. Salah satu teknologi yang merubah tata cara bersosialisasi adalah melalui aplikasi Whatsapp. Fokus penelitian ini adalah bagaimana pemanfaatan Whatsapp group sebagai media komunikasi yang dilakukan masyarakat di Desa Pandowan, Kecamatan Galur, Kulon Progo Yogyakarta. Tujuan penelitian ini adalah untuk mendeskripsikan pemanfaatan Whatsapp group sebagai media komunikasi yang dilakukan masyarakat di Desa Pandowan, Kecamatan Galur, Kulon Progo Yogyakarta. Medote penelitian ini menggunakan jenis penelitian deskriptif kualitatif. Hasil penelitian ini menunjukkan bahwa pemanfaat Whatsapp grup sebagai sarana pertukaran informasi pemerintahan desa dengan masyarakat dan sesama warga masyarakat desa. Pemanfaatan melalui whatsapp grup digunakan sebagai sarana penyampaian kebijakan pemerintahan desa, percakapan dan diskusi antar warga tentang kebijakan pemerintahan desa.

\section{Editorial Office:}

Program Studi Ilmu Komunikasi, Fakultas Dakwah dan Komunikasi, UIN Sunan Ampel Surabaya. Jl. Ahmad Yani 117 Surabaya, Jawa Timur, Indonesia.

Email: jurnalilkom@uinsby.ac.id 


\section{Pendahuluan}

Masyarakat pedesaaan tekenal dengan tradisi atau budaya berkumpul bersama, menghabiskan waktu untuk bertukar informasi baik berkaitan dengan kondisi desa meliputi: politik, agama, kesehatan, keamanan serta hal lainya yang berhubungan dengan masyarakat pedesaan secara langsung. Banyak kelompok yang terbentuk dari acara bekumpul bersama baik remaja, bapak-bapak, serta ibu-ibu. Salah satu kegiatan yang terbentuk adalah arisan mulai dari remaja, ibu-ibu, dan bapak-bapak, kegiatan ini selain sebagai sarana menabung juga sebagai sarana bersosialisasi.

Sosialisai merupakan kegiatan penting bagi masyarakat, terutama masyarakat Pedesaan. Adanya kegiatan sosialisasi dalam masyarakat membuat individu-individu dalam masyarakat belajar serta memahami tingkah laku, norma dan pekerti yang ada. Penyelaras hidup masyarakat dengan sosialisasi, dimana adanya penyesuaian serta mengenal keadaan tempat bersosialisasi. Sosialisasi mengisyaratkan suatu makna di mana setiap individu berupaya menyelaraskan hidupnya di tengah-tengah masyarakat. Dalam sosialisasi, seseorang akan mengenal dan melakukan penyesuaian dengan keadaan tempat dia bersosialisasi.

Perlunya seseorang yang tergabung atau menjadi bagian dari masyarakat

\footnotetext{
1 Anwar Anwar, "Paradigma Sosialisasi Dan Kontribusinya Terhadap Pengembangan Jiwa Beragama Anak," Komunida: Media Komunikasi Dan Dakwah 8, no. 2 (December 2018): 157, DOI:10.35905/komunida.v8i2.631.
}

melakukan sosialisasi atau interaksi dengan anggota lain, dimana akan memperkuat kebersamaan baik rasa untuk bekerja sama ataupun rasa kepedulian. Manusia merupakan makhluk sosial dimana membutuhkan media bersosialisasi, selain itu juga mempunyai kemampuan responsif, sikap, empati, serta kesadaran diri dengan orang lain. ${ }^{1}$

Sosialisasi masyarakat Pedesaan terkenal sangat tinggi, dimana ketika ada musibah atau seorang warga membutuhkan bantuan maka dengan senang hati warga yang lain akan membantu. Interaksi antar warga merupakan cara berkomunikasi serta sebagai cara penyesuaian antar warga juga sebagai pembentukan sistem nilai dalam masyarakat. Maka tidak mengherankan bila warga Pedesaan terkenal dengan banyaknya kegiatan berkumpul bersama baik saat bekerja, saat santai, serta kegiatan formal dari pagi hari hingga malam hari.

Perkembangan teknologi perlahan menambah warna cara bersosialisasi masyarakat Pedesaan, tidak hanya dengan bertemu secara langsung akan tetapi juga bertemu pada dunia maya. Teknologi informatika berperan sebagai alat transformasi atau perubahan sosial budaya pada kehidupan masyarakat. ${ }^{2}$ Sementara pertumbuhan pengguna teknologi terutama pengguna gawai semakin pesat, karena kebutuhan akses informasi untuk mendukung aktivitas sehari-hari. Banyak

\footnotetext{
${ }^{2}$ Ahmad Badari Burhan, "Pemanfaatan Teknologi Informasi Dan Komunikasi Untuk Pengembangan Ekonomi Pertanian Dan Pengentasan Kemiskinan," Jurnal Komunikasi Pembangunan 16, no. 2 (Juli 2018): 234, DOI: https://doi.org/10.46937/16201826338.
} 
orang memanfaatkan kecanggihan teknologi untuk mencari jawaban dari permasalahan hidup. Hal ini juga terjadi atau dilakukan oleh masyarakat Pedesaan, dimana mereka menggunakan teknologi untuk mencari solusi berkaitan dengan pekerjaan yang dilakukan, mencari alternatif menyelesaikan pekerjaan dengan cara lebih efisien serta menghasilkan hasil yang maksimal.

Pengguanan telepon kabel serta telpon gengam biasa berubah menjadi gawai, yakni telepon gengam yang terhubung dalam jaringan internet menjadikan warga Pedesaan banyak tertarik untuk menggunakannya. Masyarakat Pedesaan memilih gawai sebagai teknologi yang digunakan karena praktis dan murah. Pilihan penggunaan teknologi informasi dalam pemanfaatan internet memiliki berbagai pilihan aplikasi media sosial, seperti facebook, twitter, line, bbm, whatsapp, instagram, path, ask.fm, linkedin, snapchat dan beberapa media sosial lainya digunakan untuk mendapatkan informasi, berkomunikasi serta menjalin pertemanan secara online. ${ }^{3}$

Perkembangan dari sistem operasi android yakni munculnya beberapa aplikasi-aplikasi sosial yang mudah diakses pada gawai, salah satunya adalah WhatsApp. Aplikasi ini menjadikan penggunanya dapat berkomunikasi dengan bantuan internet serta dapat saling

${ }^{3}$ Trisnani, "Pemanfaatan Whatsapp Sebagai Media Komunikasi Dan Kepuasan Dalam Penyampaian Pesan Dikalangan Tokoh Masyarakat," Jurnal Komunika: Jurnal Komunikasi, Media dan Informatika 6, no. 3 (Desember 2017): 2, http://dx.doi.org/10.31504/komunika.v6i3.1227.

4 Jumiatmoko, "Whatsapp Messenger Dalam Tinjauan Manfaat Dan Adab," Wahana Akademika: membagikan berbagai macam konten sesuai dengan fitur pendukung. ${ }^{4}$ Aplikasi pesan instan ini banyak digunakan karena mudahnya pertukaran pesan baik suara maupun teks, selain itu aplikasi ini juga menyediakan fasilitas dalam pembuatan kelompok atau WhatsApp grup. Sehingga dengan adanya WhatsApp grup memudahkan terhubungnya orang-orang untuk bertukar pesan serta berdiskusi bersama.

Aplikasi media sosial tiga teratas dibawah Mark Zuckerberg yang paling banyak diunduh, posisi pertama adalah WhatsApp, Facebook, Istagram, setelah itu baru line yakni media sosial buatan korea selatan. Jumlah pengguna WhatsApp pada Mei 2018 sebanyak 1,5 miliar dan sudah mengirim sebanyak 65 miliar pesan melalui aplikasi WhatsApp maupun WhatsApp web per harinya. Setahun setelah diakuisisi Facebook, trafik pesan yang dihasilkan pengguna WhatsApp dalam sehari mencapai 30 miliar pesan. Ini jumlah pesan yang dikirim ke seluruh dunia per hari. ${ }^{5}$

Pengunaan gawai pada masyarakat pedesaan juga mewarnai tata cara bekomunikasi atau bersosialisasai. Perkumpulan tradisional atau pertemuan secara fisik (bertemu secara langsung) berubah menjadi pertemuan modern, yakni pertemuan melalui media sosial. Pertemuan modern ini terjadi setelah

Jurnal Studi Islam dan Sosial 3, no. 1 (April 2016): 51, DOI : 10.21580/wa.v3i1.872.

5 Amal Nur Ngazis, "Terus Melonjak, Berapa Jumlah Pesan Di WhatsApp Per Harinya?," diakses 9 Mei 2020,

https://www.viva.co.id/digital/teknopedia/1034634 -terus-melonjak-berapa-jumlah-pesan-diwhatsapp-per-harinya. 
banyaknya masyarakat pedesaan menggunakan gawai sebagai sarana komunikasi. Perkembangan penggunaan gawai sebagai media komunikasi modern ini terjadi setelah munculnya aplikasi pesan WhatsApp.

Dengan adanya aplikasi ini warga pedesaan membuat kelompok diskusi di dunia maya sesuai dengan kelompok sebelumnya dengan ikatan tradisional. Kelompok tersebut tergabung dalam WhatsApp Grup dimana dengan adanya grup ini menjadikan pertukaran informasi begitu cepat. Pengguaan WhatsApp di pedesaan akhirnya membawa perubahan. ${ }^{6}$ Dampak dari penggunaan gawai berbasis android tidak hanya menciptakan perubahan sosial yang melembaga akan tetapi adanya proses adaptasi penggunaan teknologi baru yang menimbukan riak-riak stratifikasi, konflik rumah tangga, serta perilaku konsumtif, akan tetapi rasionalitas nilai melalui pelanggengan dan pelembangaan nilainilai kolektivitas dan intimitasi dalam komunikasi lisan lebih kuat dan mapan. ${ }^{7}$

Penggunaan Aplikasi WhatsApp terutama fitur WhatsApp Grup memang menarik untuk diteliti dimana peneliti ingin melihat bagaimana masyarakat Pedesaan memanfaatkan aplikasi WhatsApp sebagai media komunikasi. Penelitian ini dilakukan di desa Pandowan, dimana desa ini bersatus sebagai desa berkembang, di desa inilah ada Grup

\footnotetext{
${ }^{6}$ Dwi Ridho Aulianto, "Whatsapp Sebagai Media Komunikasi," Commed: Jurnal Komunikasi Dan Media 3, no. 2 (Februari 2019): 158, https://doi.org/10.33884/commed.v3i2.1031.

7 Iskandar Zulkarnain et al., "Relasi Antara Penggunaan Android Dan Perubahan Sosial
}

WhatsApp yang menghubungkan antara warga dengan pemerintah desa. WhatsApp grup yang ada di desa ini bukan merupakan akun resmi dari pemerintah desa tetapi kehadiranya bermanfaat sebagai penghubung komunikasi antara pemerintah desa dengan warga.

\section{Kajian Pustaka}

Pada era 80-an di Eropa dan Amerika Serikat, internet sudah digunakan secara masif. Sedangkan di negara-negara berkembang internet baru booming pada akhir era 90-an dan awal tahun 2000, dan masih terbatas di wilayah kota. Namun di era sekarang perkembangan internet semakin pesat, instrumen atau alat semakin komplek menjadikan teknologi virtual dan gawai menjadi berkembang.

Gawai dimanfatkan sebagai jejaring pertemanan dan alat komunikasi melalui media sosial seperti : Facebook, Twitter, Blacberry Messenger, Yahoo Messenger, Whattsapp, Line, KakaoTalk dan sebagainya. Hal ini menjadikan semakin banyaknya manusia yang melakukan komunikasi ketika alat serta teknologi semakin berkembang dan mendukung. ${ }^{8}$

\section{Media Sosial}

Media sosial mempengaruhi perilaku masyarakat dalam pengiriman serta penerimaan informasi atau pesan. Adanya ikatan yang terbentuk oleh para pengguna

Perdesaan: Studi Perubahan Sosial Di Kabupaten Bogor Jawa Barat," Society 4, no. 2 (December 2016): 11, DOI:10.33019/society.v4i2.25.

8 Zulkarnain et al., "Relasi Antara Penggunaan Android," 2. 
media sosial, hal ini juga dipengaruhi adanya karakteristik dari media sosial diantaranya $:^{9}$

a. Jaringan: adanya jaringan yang terbentuk dari perangkat teknologi meskipun pada dunia nyata mereka tidak saling mengenal, namun bisa saling terhubung dan mengenal satu dengan yang lain

b. Informasi: merupakan hal penting dalam media sosial, informasi digunakan sebagai cara berinteraksi dengan adanya pesan yang dikirimkan

c. Arsip : aktivitas pengguna media sosial dapat tersimpan atau dapat dilihat kembali.

d. Interaksi : para pengguna dapat saling berinteraksi serta saling mengetahui aktifitas pengguna lainya dengan fitur yang ada di media sosial

e. Simulasi sosial : pengguna media sosial menggunakan media sosial sebagai cerminan pada kehidupan nyata

f. Konten : ada perbedaan media lama dengan media baru, dimana pada media lama banyak orang sebagai penikmat konten karena tidak semua orang bisa membuat konten yang akan dikirimkan. Pada media baru semua orang bisa saja membuat konten dan dikirimkan kepada pengguna lain

g. Penyebaran : penyebaran informasi atau pesan melalui perangkat bisa melihat aktifitas pengguna lainya

9 Rulli Nasrullah, Media Sosial: Perspektif Komunikasi, Budaya, dan Sosioteknologi (Bandung: Simbiosa Rekatama Media, 2016), 1. dalam menyebarkan informasi dengan fitur yang disediakan di media sosial.

Perubahan perilaku dari pengguna media sosial adalah meskipun tidak menggenal orang di dunia nyata, para pengguna bisa saling berinteraksi dengan mengirimkan pesan atau informasi kepada pengguna lain. Selain itu aktifitas yang dilakukan pada media sosial tersimpan serta dapat dilihat kembali, hal ini menjadikan apa yang sudah diunggah pada media sosial sukar untuk ditarik kembali. Media sosial menjadikan pengguna bisa membuat konten yang bisa dikirimkan kepada orang lain, tidak hanya sebagai penikmat konten. Penyebaran konten atau informasi yang ada sudah diposting pada media sosial bisa dilihat melalui fitur pendukung. Menjadikan kita tahu berapa orang yang telah membaca pesan kita dan kemana saja pesan kita dibagikan.

Pengguna media sosial dengan mudah dapat menciptakan forum, dimana indivudu-individu yang tergabung dapat menciptakan forum dan dapat saling berkomunikasi dan bertukar pikiran. Individu yang tergabung dalam forum dengan mudah berkomentar tentang topik maupun kasus yang dibahas individu lain. Individu juga membangun asumsi, emosi serta kepercayaan melalui komentar atau berkesimpulan yang memperlihatkan pola pemikiran individu dalam menggunakan media sosial. ${ }^{10}$

${ }^{10}$ C Windyo Hermawan, Cara Mudah Membuat Komunitas Online Dengan PHPBB (Yogyakarta: Andi, 2009), 2. 


\section{WhatsApp}

WhatsApp Messenger adalah bagian dari media sosial, aplikasi dengan berbasis internet menjadikan para pengguna bisa berbagi bermacam konten sesuai dengan fitur pendukung. ${ }^{11}$ Perkembangan jaman menjadikan banyak orang yang menghabiskan waktunya menggunakan teknologi termasuk berhubungan dengan kelompoknya. WhatsApp merupakan aplikasi media sosial yakni percakapan secara langsung, dapat mengirim pesan, serta terdapat fitur-fitur pendukung lainya. $^{12}$ Kecanggihan teknologi memfasilitasi para pengguna yang ingin memindahkan interaksi kelompok pada dunia nyata ke dunia maya salah satunya dengan memanfatkan Grup WhatsApp. Dengan adanya Grup WhatsApp menjadikan para penggunanya dapat menyampaikan pengumuman tertentu, berbagi ide dan sumber pembelajaran, serta mendukung terjadinya diskusi secara online. ${ }^{13}$

Pengguna aplikasi WhatsApp Messenger mengalami peningkatan dari tahun 2013, peningkatan pengguna dikarenakan adanya panjangnya durasi penggunaan serta cepatnya pemahaman penggunan fitur pada aplilasi berbasis internet ini. Tidak adanya batas ruang dan

${ }^{11}$ Ennoch Sindang, Manfaat Media Sosial Dalam Ranah Pendidikan Dan Pelatihan (Jakarta: Pusdiklat KNPK, 2013), 16.

${ }^{12}$ Amelia Anjani, Ike Atikah Ratnamulyani, and Ali Alamsyah Kusumadinata, "Penggunaan Media Komunikasi Whatsapp Terhadap Efektivitas Kinerja Karyawan," Jurnal Komunikatio 4, no. 1 (Juli 2018): 46, https://doi.org/10.30997/jk.v4i1.1211.

${ }^{13}$ Adhi Susilo, "Exploring Facebook and Whatsapp as Supporting Social Network Applications for waktu dalam penggunaan aplikasi ini. WhatsApp Messenger adaptable terhadap budaya sosial penggunanya termasuk juga adab-adab atau norma berkomunikasi penggunanya, tanpa mengurangi kuantitas, kualitas, dan modernitas cara berkomunikasi. $^{14}$ WhatsApp sebagai media sosial digunakan kepentingan bersosialisasi serta penyampaian pesan baik individu maupun kelompok. ${ }^{15}$ WhatsApp sebagai gawai mempunyai kegunaan yakni sebagai media informasi serta sangat berperan dalam memberikan dan menyebarkan informasi kepada orang lain. ${ }^{16}$

\section{Informasi}

Informasi merupakan isi pesan yang disampaikan dan diterima baik komunikator maupun komunikan, sehingga terjalin suatu hubungan. Tingkat hubungan yang terjadi antara komunikan serta komunikan terjalin karena adanya penyampaian pesan dan penerimaan pesan. Informasi merupakan fakta yang digunakan sebagai isi pesan, sedangkan data merupakan bahan mentah, setelah diolah menjadi output atau informasi. Informasi merupakan sejumlah data yang diolah melalui pengolahan data untuk menguji tingkat kebenaran serta ketercapaian sesuai dengan kebutuhan.

English Learning in Higher Education" (Conference On Professional Development In Education (PDE2014), Universitas Terbuka, Juni, 2014). http://repository.ut.ac.id/id/eprint/4930.

${ }^{14}$ Jumiatmoko, "Whatsapp Messenger," 52.

15 Trisnani, "Pemanfaatan Whatsapp," 2.

16 Sartika Sari, "Kegunaan Whatsapp Sebagai Media Informasi Dan Media STISIP Persada Bunda," Medium 6 (Desember 2018): 25, https://doi.org/10.25299/medium.2018.vol6(2).240 8. 
Empat ciri-ciri informasi yang berkualitas yakni:

a. Akurat: informasi merupakan cerminan keadaan sesungguhnya, dikatakan akurat apabila dilakukan uji coba kepada beberapa orang dan hasilnya sama.

b. Tepat waktu: informasi tersedia pada saat dibutuhkan

c. Relevan: informasi sesuai dengan yang dibutuhkan

d. Lengkap : informasi diberikan secara utuh. ${ }^{17}$

\section{Teori Pertukaran Sosial}

Teori pertukaran sosiala adalah teori yang membahas tentang adanya transaksi budaya antara individu dengan individu, dan individu dalam sebuah kelompok. Ciri khas dari teori pertukaran adalah adanya cost dan reward, yakni biaya atau pengorbanan dan penghargaan atau manfaat, yang didapat dari interaksi tersebut. Jika pengorbanan tidak sesuai dengan penghargaan maka akan berdampak pada hubungan sosial yang dilakukan, bisa mengalami kegagalan. ${ }^{18}$ Rumus teori pertukaran sosial adalah : Nilai Keuntungan - Pengorbanan. Dimana dalam menilai hubungan dengan cara menghitung keseluruhan dari sebuah hubungan dengan cara keuntungan yang

17 Deni Kurniawan Rusman and Cepi Riyana, Pembelajaran Berbasis Teknologi Informasi Dan Komunikasi (Bandung: Rajawali Pers, 2011), 7.

18 Muhammad Eka Machmud, "Transaksi Dalam Teori Exchange Behaviorism George Caspar Homans (Perspektif Ekonomi Syariah)," Iqtishadia: Jurnal Kajian Ekonomi dan Bisnis Islam STAIN Kudus 8, no. 2 (September 2015): 258, didapatkan dikurangi pengorbanan yang dilakukan. ${ }^{19}$

Di dalam kelompok perlu adanya hubungan timbal balik yang menguntungkan semua pihak. Hubungan ini terjalin karena ada kegiatan bersama yang dilakukan oleh para anggota kelompok, sehingga mempengaruhi pola interaksi serta perasaan para anggotanya. Interaksi bisa mempengaruhi atau dipengaruhi oleh hubungan timbal balik yang didapatkan. Dalam kelompok perlu adanya hubungan dan interaksi yang baik antara anggota satu dengan anggota yang lainya. Ada tiga konsep berkaitan dengan kelompok kecil yakni: kegiatan, interaksi dan perasaan. ${ }^{20}$ Kegiatan merupakan apa yang dilakukan oleh kelompok tersebut, melihat persamaan dan perbedaan kelompok. Dapat membandingkan antara persamaan serta perbedaan dalam kegiatan yang mereka lakukan misalanya dari tingkat penampilan, dan dari berbagai kegiatan yang dilakukan. Interaksi merupakan penghubung antara anggota dalam pelaksanaan kegiatan Frekuensi interaksi, siapa yang memulai interaksi, saluran apa yang digunakan dan dimana interaksi itu terjadi. Perasaan suatu hal yang sukar untuk diartikan akan tetapi perasaan ini sangat berarti bagi kebersamaan kelompok.

https://adoc.pub/amirus-sodiq-stain-kudusabstrak.html.

${ }^{19}$ Peter R Monge et al., Theories of Communication Networks (Oxford University Press, USA, 2003), 157.

${ }^{20}$ Doyle Paul Johnson, Teori Sosiologi Klasik Dan Modern 1\&2, Penerjemah: Robert MZ) (Jakarta: Gramedia Pustaka Utama, 1990), 65. 


\section{Masyarakat Pedesaan dan Teknologi}

Adanya hubungan antara masyarakat pedesaan dengan teknologi merupakan dinamika baru yakni siapa yang dipengaruhi atau mempengaruhi. Audiens atau penerima sebuah pesan merupakan individu sadar serta rasional terhadap kehadiran teknologi, adanya diskursus teknologi atas individu dan masyarakat juga dominan. ${ }^{21}$

Konsep klasik dari Mc-Luhan "media is the message" yakni menerima kontekstualitasnya karena pilihan atas media itulah yang menunjukkan seperti apa masyarakat yang menggunakannya. Medialah yang membentuk masyarakat dan bukan sebaliknya. ${ }^{22}$

\section{Metode Penelitian}

Penelitian ini menggunakan jenis penelitian kualitatif deskriptif, Penelitian kualitatif bertujuan untuk menafsirkan, mengambarkan mengenai sebuah fenomena yang terjadi dengan melibatkan berbagai metode. ${ }^{23}$ Penelitian deskiptif bertujuan untuk menjelaskan fenomena medalam untuk menemukan realitas yang kompleks serta mendapatkan pemahaman berkaitan dengan topik penelitian.

Penentuan informan dilakukan dengan teknik non probabilitas sampling yakni penentuan informan berdasarkan pertimbangan tertentu. Dalam penelitian ini informan yakni warga Pedesaan desa Pandowan serta pihak pemerintah desa

21 Thomas E Ruggiero, "Uses and Gratifications Theory in the 21st Century," Mass communication \& society 3, no. 1 (February 2000): 35, DOI:10.1207/S15327825MCS0301_02.
Pandowan yang tergabung dalam WhatsApp Grup, setidaknya tergabung minimal 6 bulan. Proses pengambilan data dilakukan dengan cara wawancara mendalam, selanjutnya hasil akan ditranskrip, dilakukan pembahasan serta melakukan penarikan kesimpulan.

\section{Hasil dan Pembahasan}

Desa Pandowan memiliki Empat potensi, yakni potensi sumber daya alam, potensi sumber daya manusia, potensi sumber daya pembangunan dan potensi sumber daya sosial budaya. Penduduk Desa Pandowan berjumlah 2.104 jiwa berasal dari 726 kepala keluarga, dari jumlah tersebut, 174 kepala keluarga merupakan KK miskin.

Sementara Status desa Pandowan berdasarkan indeks desa membangun termasuk desa berkembang. Dengan status desa berkembang yang merupakan peningkatan dari status desa tertinggal, banyak warga yang sudah terbuka dengan teknologi. Banyak masyarakat yang menggunakan gawai sebagai alat komunikasi, mencari informasi, hiburan dan sebagai media untuk berbisnis.

\section{WhatsApp Grup sebagai Media Interaksi Masyarakat Pedesaan}

Kebiasaan berkumpul bersama antara warga, menjadi ciri yang tidak dapat dipisahkan dari masyarakat Pedesaan. Sementara teknologi perlahan-lahan telah

${ }^{22}$ Marshall McLuhan, Understanding Media: The Extensions of Man. 1964 (Pour comprendre les media: Les prolongements, 1994), 7.

${ }^{23}$ Lexy J Moleong, Metode Penelitian Kualitatif (Bandung: Remaja Rosdakarya, 2007), 6. 
merubah kebiasaan serta nilai-nilai yang ada dimasyarakat, dimana pada WhatsApp Grup diatur adanya sebuah aturan tertulis untuk anggota grup. Dalam konteks ini telah terjadi perubahan yang biasanya aturan dibuat secara kesepakatan tanpa tertulis dan sekarang aturan di dunia maya ditulis untuk disepakati bersama.

Dari keseluruhan informan ada satu informan yang tidak memahmi adanya aturan yang ada di deskripsi WhatsApp Grup. Jawaban informan tersebut: Tidak memahami adanya aturan. Sedangkan informan yang lain mengetahui tentang adanya aturan yang ada pada deskripsi WhatsApp Grup, yakni: aturan postingan di WhatsApp Grup, Larangan di Whatsap Grup, dan aturan yang fleksibel yang ada WhatsApp Grup, hal ini diungkapkan oleh informan 3 bahwa aturan pada WhatsApp Grup Kelurahan sangat fleksibel :

\section{Sangat fleksibel}

Aturan yang ada pada deskripsi WhatsApp Grup adalah perubahan norma pada masyarakat karena pengaruh teknologi. Masyarakat pedesaan dulunya mempunyai aturan, atau norma yang sering disebut dengan unggah-ungguh, dibuat berdasarkan kebiasaan dan tanpa ditulis. Sekarang menjadi tertulis dan seragam dengan aturan pada WhatsaApp Grup pada umumnya bahkan mungkin aturan ini sama seluruh Indonesia. Hal ini menghilangkan aturan kekhasan suatu daerah berkaitan dengan penggunaan media sosial. Meskipun aturan pada deskripsi seragam

24 Ririn Puspita Tutiasri, Ade Kusuma, and Sumardjijati Sumardjijati, "Perilaku Remaja Dalam Penyebaran Hoax Di Grup WhatsApp,' Jurnal Ilmu pada umumnya, namun masih ada nilai yang dipertahankan oleh masyarakat, hal ini diungkapkan oleh anggota grup sekaligus aparat pemerintah desa:

"Kalau hoax langsung kita tanggapi, selama spam itu masih sopan kita biarkan, tapi kalau sudah mengandung SARA adminnya langsung bersikap keras",

Spam masih digunakan sebagai bahan berkomunikasi atau interaksi oleh para anggota. Misalnya membagikan kegiatan sehari-hari atau pengalaman hidup yang sebenarnya tidak ada hubunganya dengan anggota WhatsApp Grup lainya. Spam yang dilakukan oleh warga menjadi pemicu terjadinya komunikasi. Pada WhatsApp Grup desa Pandowan informasi yang dibagikan menurut jawaban dari informan dapat dikategorikan sebagai berikut :

Berita berkaitan dengan Kalurahan Pandowan, Tentang Kegiatan yang dilaksanakan, Sebagai tempat silaturahmi, Sebagai tempat pertukaran informasi atau diskusi antara pemerintah dan warga desa Pandowan. Pertukaran informasi pada WhatsApp Grup menjadi pertukaran sosial antara para anggota grup. Mereka mendapatkan informasi berkaitan tentang informasi tentang kalurahan baik berkaitan tentang kegiatan, maupun kondisi dari warga kalurahan. Para anggota WhatsApp Grup membagikan informasi dengan tujuan berinteraksi dengan sesama anggota grup. ${ }^{24}$

Komunikasi 2, no. 1 (Juli 2019): 6, https://doi.org/10.33005/jkom.v2i1.36. 
Pesan yang disampaikan hendaknya diseleksi terlebih dahulu apakah merupakan pesan yang masuk kriteria boleh dibagikan atau tidak pada grup, menginggat sebuah grup juga mempunyai aturan tersendri. Akan tetapi banyak anggota dari Whats App Grup yang tidak memahami aturan yang tertulis pada diskirpsi.

Beragam tanggapan dari para informan berkaitan dengan pesan atau informasi terutama pertanyaan yang ditanyakan kepada pihak pemerintah kalurahan. Kebanyakan informan menjawab pertanyaan yang disampaikan kepada pihak kalurahan melalui WhatsApp Grup lalu mendapatkan tanggapan dari pihak kalurahan. "Iya mendapatkan jawaban dari grup, contohnya lampu depan kalurahan kok mati ? Langsung direspon dan ada yang menghubungi pihak PLN

Selain itu pertanyaan berkaitan dengan kegiatan yang dilaksanakan oleh pihak pemerintahan kalurahan juga mendapatkan tanggapan yang baik : Kadang kadang pertanyaan yang ada di grup langsung direspon dengan baik, contohya kemarin berkaitan dengan Info berita kegiatan.

Akan tetapi ada juga informan yang menjawab : Rata rata hanya Tanggapan Bukan jawaban. Informan ke 4 ini menjawab pertanyaan, apa yang disampaikan oleh dia saat digrup bukan merupakan jawab melainkan tanggapan. Jawaban maupun tanggapan dari pesan yang dikirimkan seseorang dalam suatu grup merupakan hal penting, dimana dia merasa dihargai serta diperhatikan oleh anggota WhatsApp Grup lainya. Rasa solidaritas dan rasa keakraban akan terbentuk dari adanya jawaban maupu tanggapan dari para anggota.

\section{WhatsApp Grup Media Penyampaian dan Pembuat Kebijakan Pemerintah}

Salah satu kemajuan teknologi yang digunakan masyarakat perdesaan adalah Gawai. Dengan teknologi berbasis internet ini gawai dapat menggunakan beberapa aplikasi lain sesuai kebutuhan pemiliknya. Aplikasi yang sering digunakan warga pedesaan sebagai media berkomunikasi dan dianggap paling efektif adalah WhatsApp Grup. Dimana tidak ada batasan berapa banyak orang yang dapat bergabung digrup. Menurut informan keefektifan penyampaian informasi pemerintah kalurahan digolongkan menjadi dua pendapat, yakni Efektif, belum efektif/belum maksimal.

Efektif menurut informan maksudya apa yang diinformasikan pemerintah melalui WhatsApp grup sesuai dengan apa yang dibutuhkan oleh warga. Misalnya tentang tata cara pembuatan atau cetak EKTP, protokol kesehatan, informasi pertanian dan informasi yang berhubungan dengan warga. WhatsApp Grup kalurahan dianggap efektif karena infomasi yang disampaikan dengan cepat dapat tersebar keseluruh anggota grup.

Belum efektif, maksudnya karena hanya bersifat informatif saja. Belum terlalu efektif, karen biasanya beritaberitanya sifatnya umum hanya sebagai sarana silaturohmi. Beberapa informan menganggap WhatsApp Grup hanya digunakan sebagai sarana silaturahim, menginformasikan kegiatan yang 
dilakukan oleh warga. Pemerintah kalurahan Pandowan juga menjadikan WhatsApp Grup sebagai media penyampai informasi resmi yang bersifat kebijakan. Dimana apa yang didiskusikan oleh warga pada WhatsApp grup kemudian digunakan sebagai bahan masukan untuk pemerintah, diantaranya sebagai berikut:

"Iya, selalu dibahas, misalnya seperti sekarang masalah karantina itu, kok berbeda, yang disana seperti itu, yang disini seperti ini, kok perlakuannya berbeda. Nah, kita bahas yang sesuai aturan yang mana, terus kita mengadakan Rakor khusus masalah Covid ini bersama relawan, kita menyampaikan tanggapan karena kita belum satu visi, agar nanti saat memberi jawaban kepada warga sama, meberikan perlakuan juga sama”.

Warga Desa Pandowan dan pemerintah desa setempat akhirnya memanfatkan perkembangan teknologi WhatsApp Grup, sebagai media informasi dan sekaligus memberikan masukan tentang proses pembuatan kebijakan.

WhatsApp Grup bagi masayarakat desa Pandowan sangat berarti karena dengan adanya grup ini berbagai informasi dibagikan. Informan 2 dan 5 menjelaskan apa yang dibagikan pada grup yakni : Berbagai macam informasi.

Infoman 3 menjawab infomasi yang disampaikan baik bernilai berita maupun informasi ringan yang bisa dimanfatkan untuk kepentingan warga perdesaan. Yang dibahas biasanya berita yang ringanringan.

Dari berita atau informasi baik yang benar maupun hoax dibagikan yang digunakan sebagai bahan interaksi antar anggota WhatsApp Grup. Secara spesifik informan 4 menjawab pesan yang dibagikan dalam gup yakni :Variatif, masalah informasi pembangunan, kesehatan. keamanan, kematian, budaya dan lain-lain.

Meskipun WhatsApp dinilai sebagai media yang mempunyai kegunaan sebagai media informasi serta sangat berperan dalam memberikan dan menyebarkan informasi kepada orang lain, ${ }^{25}$ tetapi WhatsApp Grup juga dinilai belum efektif bila dibandingkan ketika bertemu secara langgsung. Hal ini diungkapkan oleh informan 2 yang menganggap Whats App Grup masih kurang efektif karena didalam WhatsApp Grup yang disampaikan hanya garis besarnya saja. Langsung. Karena kalau WhatsApp Grup cuma garis besarnya Informan 3 juga memberikan jawaban yang sama dimana kalau penyampaian informasi berkaitan dengan pemerintahan lebih efektif disampaikan secara langsung, hal ini dikarenakan tidak semua warga tergabung dalam grup dan tidak semua memiliki pemahaman yang sama, tentang penyampaian informasi dengan menggunakan WhatsApp Grup, informan 3 menjelaskan;

"Kalau berhubungan dengan pemerintahan kalurahan lebih efektif secara langsung misal lewat pertemuanpertemuan karena yang masuk grup tidak semua warga, hanya yang punya kemauan aja."

Akan tetapi WhatsApp Grup sangat efektif digunakan untuk menyampaikan informasi kepada warga pedesaan ketika masa pandemi covid-19. Dimana pada masa pandemi ini pertemuan warga sangat

\footnotetext{
${ }^{25}$ Sartika Sari, "Kegunaan Whatsapp," 17.
} 
dibatasi dan harus menjaga jarak untuk mengurangi penyebaran virus covid-19. Hal ini menjadikan informan 5 menjawab lebih efektif menggunakan WhatsApp Grup.

"WhatsApp Grup, Ya bisa sebagai sarana menyampaikan informasi atau kebijakan dari pemerintah kepada warga pada saat masa pandemi ini.'

Media WhatsApp Grup juga sangat bermanfaat ketika ada wabah yang menjadikan para warga atau orang-orang untuk berkumpul bersama, atau mengurangi interaksi. WhatsApp Grup digunakan sebagai sarana untuk berkordinasi selain membagikan pesan atau informasi. Hal ini diungkapkan oleh informan 3, dimana koordinasi menjenguk orang sakit dilakukan dengan menggunakan WhatsApp Grup.

"WhatsApp Grup bisa mengurangi berkumpul dalam masa pendemi . Contoh kalau menengok orang sakit sementara hanya perwakilan."

WhatsApp Grup pada masa pandemi Covid-19 ini dimanfaatkan oleh para penggunanya terutama daerah perdesaan sebagai sarana koordinasi ketika ada suatu kegiatan. Warga desa meskipun masa pandemi tetap menjalin sliaturahmi dan menjaga hubungan baik, dan tetap menjalankan protokol kesehatan, dimana hanya perwakilan saja yang menjenguk ketika ada warga sakit. Meskipun kurang efektif dibandingkan dengan bertemu langsung, WhatsApp Grup dinilai sebagai solusi ketika masa pandemi ini dengan menyampaikan informasi kepada warga, sangat bagus bisa Menjadi Salah Satu Sarana untuk sosialisasi.
Informasi yang disampaikan ketika masa pandemi erat kaitanya dengan pandemi yang sedang terjadi. Misalnya informasi tentang bagaimana menjalankan protokol kesehatan, informasi berkaitan dengan tata cara isolasi mandiri, akses kesehatan bahkan informasi pertambahan atau pengurangan orang yang terindikasi positif karena terkena virus covid-19. Hal ini disampaikan oleh informan 2 tentang manfaat informasi WhatsApp pada masa pandemi : "Bisa tau info daerah mana yg positif."

Berbagai informasi dibagikan baik dari pemerintah kalurahan maupun dari warga pada masa pandemi ini. Beberapa informasi yang didapatkan oleh para warga saat menggunakan WhatsApp Grup dan berinteraksi saat masa pandemi seperti : Informasi tentang instruksi mengikuti peraturan pemerintah tentang Peraturan covid 19, yakni menggunakan masker. Selain itu informasi kedatangan warga yang sedang merantau, untuk tidak mudik juga menjadi perhatin warga. Hal ini diungkapkan oleh informan 4 yakni:

"Kita di rantau ya ada yang kita taati misalkan pada waktu lebaran dilarang pulang kampung ya gak jadi pulang kampung, walaupun tiket pesawat sudah kita beli”

Informasi yang dibagikan oleh pihak pemerintah desa menggunakan media WhatsApp Grup sangat ditaati oleh para anggota grup, mengingat informasi yang dibagikan bermanfaat untuk masyarakat. Terutama pada masa pandemi covid-19 koordinasi masyarkat serta penyampaian kebijakan hanya bisa disampaikan melalui media, dimana dengan media tersebut 
masyarakat tidak perlu berkumpul. WhatsApp Grup merupakan salah satu media yang efektif untuk menyampaikan informasi kepada para penggunanya, karena bisa terjadi interkasi melalui jawaban, komentar, maupun tanggapan yang dibagikan anggota grup lainya.

\section{Kesimpulan}

Pertukaran sosial berupa informasi terjadi pada WhatsApp Grup sebagai media komunikasi. Hasil pertukaran dalam WhatsApp grup oleh warga dianggap bernilai positif, tidak terlihat nilai rugi atau negatif, karena apa yang disampaikan pada grup merupakan informasi berkaitan dengan warga. Masyarakat pedesaan baik pemerintah desa dan warga menggunakan aplikasi WhatsApp grup sebagai sarana penyampai kebijakan, penerima kebijakan serta pembuatan kebijakan. Pemerintah desa mengamati apa yang sedang dibicarakan masyarakat menyangkut kepentingan bersama melakui diskusi pada WhatsApp Grup.

Namun ada juga yang berpendapat penyampaian kebijakan dengan menggunakan WhatsApp Grup dirasa belum efektif, mereka beranggapan lebih baik bertemu secara langsung atau luring. Pesan akan efektif ketika penerima pesan dalam kondisi yang fokus dimana, dengan bertemu secara langsung menjadikan penerima pesan lebih fokus. Akan tetapi karena ada pandemi covid-19 menjadikan adanya pengaturan jarak, dan mengurangi kerumunan, menjadikan WhatsApp Grup menjadikan media ini efektif digunakan sebagai sarana penyampaian kebijakan atau sebagai sarana berbagi informasi.
Saran untuk penelitian selanjutnya, penelitian selanjutnya bisa meneliti pergeseran budaya masyarakat perdesaan akibat dari interaksi WhatsApp Grup.

\section{Daftar Pustaka}

Anjani, Amelia, et. al. "Penggunaan Media Komunikasi Whatsapp terhadap Efektivitas Kinerja Karyawan." Jurnal Komunikatio 4, no. 1 (Juli 2018): $\quad$ 41-50. https://doi.org/10.30997/jk.v4i1.121 1.

Anwar, Anwar. "Paradigma Sosialisasi Dan Kontribusinya Terhadap Pengembangan Jiwa Beragama Anak." Komunida: Media Komunikasi Dan Dakwah 8, no. 2 (December 2018): 155-167. DOI:10.35905/komunida.v8i2.631.

Aulianto, Dwi Ridho. "Whatsapp Sebagai Media Komunikasi." Commed: Jurnal Komunikasi Dan Media 3, no. 2 (Februari 2019): 150-158. https://doi.org/10.33884/commed.v3 i2.1031.

Burhan, Ahmad Badari. "Pemanfaatan Teknologi Informasi dan Komunikasi untuk Pengembangan Ekonomi Pertanian dan Pengentasan Kemiskinan." Jurnal Komunikasi Pembangunan 16, no. 2 (Juli 2018): 233-247.

DOI: https://doi.org/10.46937/16201 826338.

Ennoch Sindang. Manfaat Media Sosial Dalam Ranah Pendidikan dan Pelatihan. Jakarta: Pusdiklat KNPK, 2013.

Hermawan, C Windyo. Cara Mudah Membuat Komunitas Online Dengan PHPBB. Yogyakarta: Andi, 2009.

Johnson, Doyle Paul. Teori Sosiologi Klasik Dan Modern 1\&2. 
Penerjemah: Robert MZ). Jakarta: Gramedia Pustaka Utama, 1990.

Jumiatmoko. "Whatsapp Messenger Dalam Tinjauan Manfaat Dan Adab." Wahana Akademika: Jurnal Studi Islam dan Sosial 3, no. 1 (April 2016): 51-66.

DOI: $10.21580 /$ wa.v3i1.872.

Machmud, Muhammad Eka. "Transaksi Dalam Teori Exchange Behaviorism George Caspar Homans (Perspektif Ekonomi Syariah)." Iqtishadia: Jurnal Kajian Ekonomi dan Bisnis Islam STAIN Kudus 8, no. 2 (September 2015): 257-280. https://adoc.pub/amirus-sodiq-stainkudus-abstrak.html.

McLuhan, Marshall. Understanding Media: The Extensions of Man. 1964. Pour comprendre les media: Les prolongements, 1994.

\section{Moleong, Lexy J. Metode Penelitian Kualitatif. Bandung: Remaja Rosdakarya, 2007.}

Monge, Peter $\mathrm{R}$. et al. Theories of Communication Networks. USA: Oxford University Press, 2003.

Nasrullah, Rulli. Media Sosial: Perspektif Komunikasi, Budaya, dan Sosioteknologi. Bandung: Simbiosa Rekatama Media, 2016.

Ngazis, Amal Nur. "Terus Melonjak, Berapa Jumlah Pesan di WhatsApp Per Harinya?." diakses 9 Mei 2020. https://www.viva.co.id/digital/tekno pedia/1034634-terus-melonjakberapa-jumlah-pesan-di-whatsappper-harinya.

Ruggiero, Thomas E. "Uses and Gratifications Theory in the 21st Century." Mass communication \& society 3, no. 1 (February 2000): 3 37.

DOI:10.1207/S15327825MCS0301_ 02.
Rusman, Deni Kurniawan, dan Cepi Riyana. Pembelajaran Berbasis Teknologi Informasi dan Komunikasi. Bandung: Rajawali Pers, 2011.

Sari, Sartika. "Kegunaan Whatsapp Sebagai Media Informasi Dan Media STISIP Persada Bunda." Medium 6 (Desember 2018): 15-26. https://doi.org/10.25299/medium.20 18.vol6(2).2408.

Susilo, Adhi. "Exploring Facebook and Whatsapp as Supporting Social Network Applications for English Learning in Higher Education." (Conference On Professional Development In Education (PDE2014). Universitas Terbuka. Juni, 2014). http://repository.ut.ac.id/id/eprint/49 30

Trisnani. "Pemanfaatan Whatsapp Sebagai Media Komunikasi Dan Kepuasan Dalam Penyampaian Pesan Dikalangan Tokoh Masyarakat." Jurnal Komunika: Jurnal Komunikasi, Media dan Informatika 6, no. 3 (Desember 2017): 1-12. http://dx.doi.org/10.31504/komunik a.v6i3.1227.

Tutiasri, Ririn Puspita, et. all. "Perilaku Remaja Dalam Penyebaran Hoax Di Grup WhatsApp." Jurnal Ilmu Komunikasi 2, no. 1 (Juli 2019): 1-8. https://doi.org/10.33005/jkom.v2i1. 36.

Zulkarnain, Iskandar et al. "Relasi Antara Penggunaan Android dan Perubahan Sosial Perdesaan: Studi Perubahan Sosial Di Kabupaten Bogor Jawa Barat." Society 4, no. 2 (December 2016): 1-14. DOI:10.33019/society.v4i2.25. 